\title{
Viability and receptivity of reproductive structures in Lima bean (Phaseolus lunatus L.) for improvement programs
}

\author{
Menneky Prudêncio Lisboa da Silva ${ }^{1} \oplus$, Karoline Lays Santos Borges ${ }^{1} \oplus$, \\ Priscila Alves Barroso ${ }^{1 *} \mathbb{0}$, Artur Mendes Medeiros ${ }^{1} \mathbb{D}$, Silvokleio da Costa Silva ${ }^{1}$ \\ 1 Universidade Federal do Piauí, Bom Jesus, PI, Brasil. E-mail: mennekysakura3@gmail.com; karollays159@gmail.com; pa.barroso@ufpi.edu.br; artur.medeiros@ufpi.edu.br;
silvokleio@ufpi.edu.br
}

ABSTRACT: Artificial hybridization in Phaseolus lunatus L. is still little used in genetic improvement programs in Brazil due to the low establishment percentages. This work aimed to evaluate pollen viability and stigma receptivity in different Lima bean genotypes throughout the day. Accessions 'Roxinha -MT' and 'Cana Longa-PB' were used in the experiment. Five flower buds were collected from each genotype at 6:00 a.m., 10:00 a.m., 2:00 p.m., and 6:00 p.m. The stigma receptivity was determined using $3 \%$ hydrogen peroxide, whereas pollen viability was determined with $2 \%$ acetocarmine colouration. The genotype and time factors acted independently on the percentage of viable and non-viable pollen grains and stigma receptivity. The genotype 'Roxinha' presented $88.54 \%$ viable pollen grains, a value $84.27 \%$ higher than that of the 'Cana Longa' genotype. This percentage varied as a function of time, with the highest means observed at 6:00 a.m. Stigma receptivity was influenced only by the time of the day, undergoing a great reduction in receptivity, from $88 \%$ in the early morning to slightly more than $40 \%$ around noon. These results indicate that 6:00 a.m. is the most suitable time to perform artificial crosses in Lima bean plants.

Key words: environment; genetic improvement; genotype; hybridization; pollen viability; stigma receptivity

\section{Viabilidade e receptividade de estruturas reprodutivas de feijão-fava (Phaseolus lunatus L.) para programas de melhoramento}

RESUMO: A hibridação artificial em Phaseolus lunatus L. ainda é pouco utilizada nos programas de melhoramento genético no Brasil devido as baixas porcentagens de pegamento. Objetivou-se avaliar a viabilidade do pólen e a receptividade do estigma em diferentes genótipos de feijão-fava ao longo do dia. Foram utilizados os acessos Roxinha -MT e Cana Longa-PB. Cinco botões florais foram coletados de cada genótipo nos horários de 06:00, 10:00, 14:00 e 18:00 horas. A receptividade estigmática foi determinada com o uso de Peroxido de hidrogênio 3\% e a viabilidade do pólen com a coloração de Carmim acético a $2 \%$. Os fatores genótipos e horário atuaram de forma independente no percentual de pólens viáveis, inviáveis e receptividade do estigma. No genótipo Rosinha foram observados $88,54 \%$ de pólen viáveis, superior ao Cana Longa com $84,27 \%$. Este percentual variou em função do horário, com as maiores médias observadas as 6:00h. A receptividade do estigma foi influenciada apenas pelo horário do dia, sofrendo uma grande redução na porcentagem de receptividade de $88 \%$ no início da manhã, para pouco mais de $40 \%$ por volta do meio dia. Estes resultados indicam que 6:00h é o horário ideal para realização de cruzamentos artificiais em feijão-fava.

Palavras-chave: ambiente; melhoramento genético; genótipo; hibridação; viabilidade do pólen; receptividade do estigma

\footnotetext{
* Priscila Alves Barroso - E-mail: pa.barroso@ufpi.edu.br (Corresponding author)

Associate Editor: Mário de Andrade Lira Júnior
} 


\section{Introduction}

Phaseolus lunatus L., also known as Lima bean, is a legume species with great variability dispersed throughout the country, especially in the northeastern states. Its seeds are used for cooking worldwide, ranking as the second species of its genus with greater socioeconomic importance (Ormeño Orrillo et al., 2015). However, the mean yield observed in Brazil is still far from the indices obtained in other producing regions. In the United States, for example, which is considered to be one of the largest producers, mean yields above $2.500 \mathrm{~kg} \mathrm{ha}^{-1}$ were easily achieved (USDA, 2018; IBGE, 2020), compared to the $313 \mathrm{~kg} \mathrm{ha}^{-1}$ produced in the entire Northeast Region of Brazil in 2018 (IBGE, 2020). The low yield may be associated, among other factors, with the absence of genotypes adapted to local conditions, highlighting the importance of scientific research on genetics and improvement for the species.

Artificial crossing can be employed in the improvement of Lima bean to gather in a cultivar the agronomical traits that make this variety superior to its parents and with that obtaining greater profitability to the producer.

Furthermore, pollination is a fundamental step in the production of these plants since it allows the formation of fruits and seeds (Barbosa \& Sousa, 2016). The success of pollination will depend on stigma receptivity and pollen viability, which constitute the effective beginning of the pollen-pistil interaction, ensuring the production of seeds of vigorous lineages and/or hybrids in breeding programs (Shivanna, 2003; Kaefer et al., 2016).

Pollen must present aptitude for success in production, with its quality being associated with its viability (Vianna et al., 2006). A stigma, in turn, is considered receptive when it can support pollen germination (Sanzol \& Herrero, 2001). The duration of receptivity can vary significantly depending on the species (Dafni, 1992; Shivanna, 2003). According to Dafni (1992), stigma receptivity and pollen viability should be investigated to identify the optimal times and developmental stages of flowers for artificial pollination procedures.

Studies related to pollination, such as the viability and receptivity of reproductive structures, are still scarce for Phaseolus lunatus L., which may explain the lack of success in hybridizations in this species since they constitute important parameters in plant genetic improvement programs. A low percentage of fruit establishment originating from crosses has been reported for the genus Phaseolus, including $P$. lunatus. Segundo (2010) tested four artificial hybridization methods in $P$. lunatus and obtained less than 3\% fruit establishment. In $P$. vulgaris, up to $30 \%$ of the establishment has been reported (Vaid, 1990; Carpentieri-Pípolo et al., 2001).

Assessments of pollen viability and stigma receptivity are not common practices in Lima bean breeding programs. To date, no Lima bean cultivars have originated from introduction or developed in breeding programs using the variability obtained via hybridization, protected and registered with the Ministry of Agriculture, Livestock and Food Supply -
MAPA (Brasil, 2020). From this perspective, this work aimed to evaluate pollen viability and stigma receptivity at distinct times of the day and determine the best time for crossing in Lima bean genotypes.

\section{Materials and Methods}

The work was conducted at the Federal University of Piauí (UFPI), Campus Professora Cinobelina Elvas (CPCE), in Bom Jesus, $\mathrm{PI}$, at $09^{\circ} 04^{\prime} 28^{\prime \prime}$ south latitude, $44^{\circ} 21^{\prime} 31^{\prime \prime}$ west longitude, and $277 \mathrm{~m}$ elevation.

The municipality belongs to the semiarid region of the state of Piauí, characterized by a hot and humid climate, classified by Köppen as Cwa (temperate with dry winter and summer and autumn rains), with a mean rainfall varying from 900 to $1200 \mathrm{~mm}$ year ${ }^{-1}$ and a mean temperature of $26.2^{\circ} \mathrm{C}$, according to the data by INMET (2021). The soil of the region is classified as a Dystrophic Yellow Latosol with a predominant sandy texture.

Two Lima bean accessions belonging to the Germplasm Bank of the Federal University of Piauí were used: 'Cana Longa' - PB and 'Roxinha' - MT. The accessions were arranged in an open field experiment following a randomized block design, aiming at evaluating the agronomic performance of 10 different Lima bean genotypes under the conditions of Bom Jesus-PI.

At flowering, flower clusters were randomly selected in both Lima bean genotypes, collected at 6:00 a.m., 10:00 a.m., 2:00 p.m., and 6:00 p.m. The temperature and relative humidity data during the day are shown in Figure 1 . The collection was performed using pliers to avoid damage. The material was then identified and stored in a polystyrene box containing moist cotton. After the collection process, the clusters were immediately transported to the Laboratory of Genetics of CPCE/UFPI for the analyses.

For the test of stigma receptivity, 5 unripe flower buds/ time with average size were chosen (Figure $2 \mathrm{~A}$ ). The size of

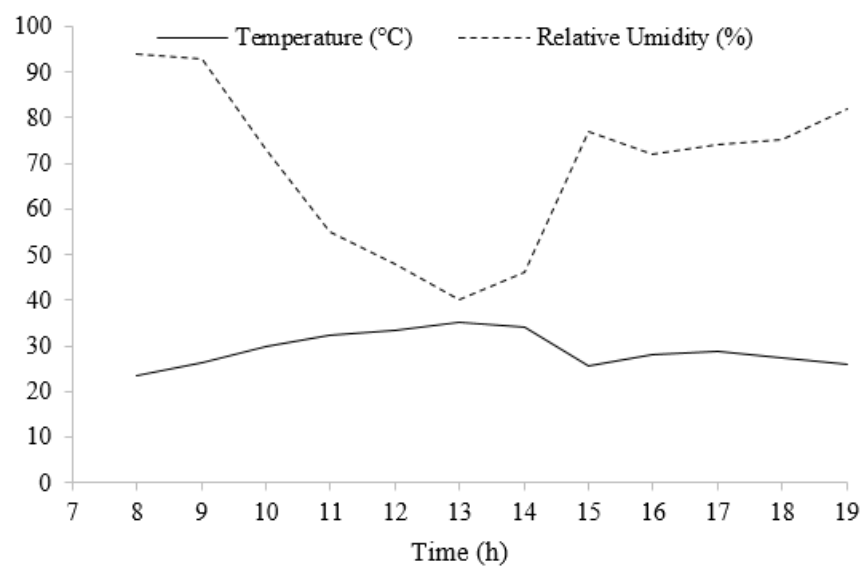

Source: INMET (2021).

Figure 1. Temperature $\left({ }^{\circ} \mathrm{C}\right)$ and relative humidity (\%) in the city of Bom Jesus-PI during the collection of Lima bean flower buds (Phaseolus lunatus) for analysis of viability and receptivity of reproductive structures in February 2019. 
the flower bud was determined in previous studies by the same authors, in which they compared pollen viability in different developmental stages. With the aid of tweezers, the structures that surround the stigma were removed, such as wings, banner, and keel, as well as anthers and style, leaving only the stigma attached to the peduncle, according to the sequence presented in Figure $2 \mathrm{~B}$.

The already opened buds were taken to a stereomicroscope (10x) on Petri dishes, where with the aid of a liquid dropper, one drop of $3 \%$ hydrogen peroxide was used on the stigmatic surface of each flower bud. The stigmatic receptivity (ER) was estimated by observing the amount of bubbles formed on the surface of the stigma at $0,30,60$, and $100 \%$.

For the pollen viability test, emasculation of 5 flower buds/time was performed in each of the genotypes by removing the anthers and placing them on microscope slides. Each anther was opened for the removal of pollen grains. A drop of $2 \%$ acetic carmine was used in each slide, and the slides were immediately taken for microscope counting using a $4 \mathrm{x}$ objective lens. A total of 500 pollen grains were counted for each flower bud, estimating the percentage of viable (PV) and non-viable grains (PIV) by the presence (viable) or absence (non-viable) of carmine coloring.

The experiment was analyzed in a completely randomized design in a $2 \times 4$ factorial scheme (genotypes $x$ evaluation times) with 5 replications (flowers). The data were subjected to analysis of variance, and when detecting significant differences, they were compared by the F-test. Regression models were adjusted for the time variable. Spearman's correlation coefficient between the percentage of viable pollen grains and stigma receptivity was also estimated, and the significance was tested by Student's t-test. All analyses were performed in R software, version 3.5.3 (R Core Team, 2019).
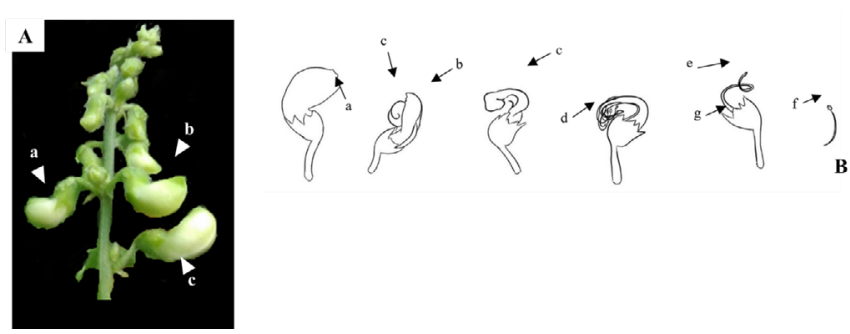

Figure 2. A: Flower buds of Phaseolus lunatus L. Arranged in a cluster. a: small ( $\leq 2.9 \mathrm{~mm}$ ); b: average (3 to $3.5 \mathrm{~mm}$ ); c: large (> $3.5 \mathrm{~mm}$ ). B: flower before anthesis; a: wing, b: banner; C: flower bud; c: keel; d: reproductive structures (stigma and anthers); e: stigma; f: anther; g: peduncle.

\section{Results and Discussion}

No significant interaction was observed $(p \leq 0.05)$ between the genotypes and times analyzed (Table 1), meaning that the factors act independently in the determination of pollen viability and stigma receptivity. This result is important for breeding programs since a determined time can be used to perform crosses in more than one genotype. There was
Table 1. Summary of the analysis of variance and mean main effect of the genotypes for pollen viability and stigma receptivity of Lima bean genotypes (Phaseolus lunatus L.), at different times.

\begin{tabular}{cccc}
\hline Source of variation & PV & PIV & ER \\
\hline Genotype & $181.902^{*}$ & $181.902^{*}$ & $10.0 \mathrm{~ns}$ \\
Time & $265.912^{*}$ & $265.912^{*}$ & $4750.0^{*}$ \\
G x H & $49.565^{\text {ns }}$ & $49.505^{\text {ns }}$ & $163.3^{\text {ns }}$ \\
CV \% & 5.77 & 36.67 & 28.28 \\
\hline Genotype & PV (\%) & PIV (\%) & ER (\%) \\
\hline Roxinha - MT & $88.54 \mathrm{a}^{1}$ & $11.46 \mathrm{~b}$ & $62.00 \mathrm{a}$ \\
Cana Longa - PB & $84.27 \mathrm{~b}$ & $15.73 \mathrm{a}$ & $63.00 \mathrm{a}$ \\
\hline
\end{tabular}

PV - Percentage of viable pollen; PIV - Percentage of non-viable pollen; ER - Stigmatic receptivity.

*, ns Significant and non-significant at $5 \%$ by $\mathrm{F}$ test.

${ }^{1}$ Means followed by the same letter in the same column do not present significant differences at a $5 \%$ level of probability by Tukey's test.

a significant difference between the levels of the genotypic factors and the time levels ( $p \leq 0.05$ ) for the PV variable and consequently for the PIV. The ER was influenced only by the times.

Viable and non-viable pollen grains were observed in both genotypes (Figure $3 \mathrm{~A}$ ), with the $2 \%$ acetocarmine solution being efficient in determining pollen viability in $P$. lunnatus L. The coloration occurs due to the plenitude of cellular structures, such as the nucleus (Munhoz et al., 2008). Little stained and deformed pollen grains were also observed and classified as non-viable (Figure 3A).
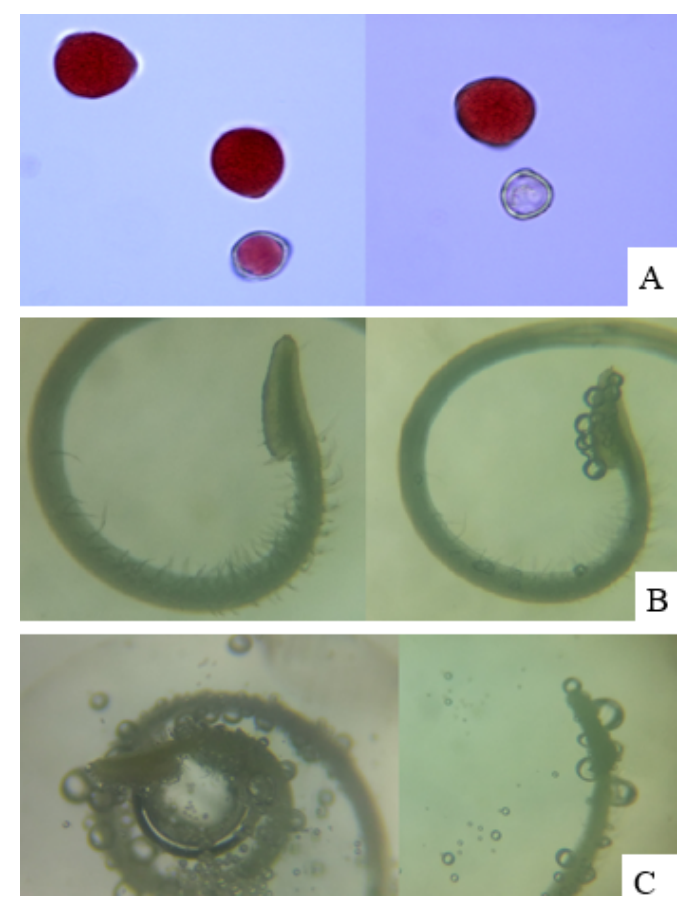

Figure 3. A) Pollen grains of Phaseolus lunatus L. stained with acetocarmine (viable) and not stained and/or slightly stained pollen grains with anomalous (non-viable) B) Stigma of Phaseolus lunatus L. removed from flower buds without hydrogen peroxide and stigmatic surface with bubbling at $60 \%$ receptivity. C) Degeneration of the stigma and style indicated by the activity of peroxidases in a pollinated stigma and nonpollinated stigma presenting bubbling in all its structures. 
The genotype 'Roxinha' obtained a higher number of viable pollen grains $(8,854$ out of 10,000$)$, corresponding to $88.54 \%$, differing statistically from the 'Cana Longa' genotype, with $84.27 \%$ (Table 1). In a work performed by Jesus et al. (2018) testing pollen viability in nine accessions of Phaseolus lunatus L., values ranging from $77 \%$ to $95 \%$ were verified for this variable, concluding that genotypes of the same species may present variability regarding pollen viability. In this manner, in addition to agronomical traits, pollen viability studies should be performed to aid in the selection of parents in breeding programs. The percentage of inviable pollen grains is complementary to the percentage of viable pollen grains, presenting mean percentages of $11.46 \%$ and $15.73 \%$ for genotypes 'Roxinha' and 'Cana Longa', respectively.

Pollen viability also varied as a function of time (Figure 4). The quadratic behavior reveals that the highest means of pollen viability are observed in the early hours of the day, with a gradual reduction, reaching the lowest percentage at 1:14 p.m., which corresponds to approximately $81.4 \%$ of viable pollen grains (Figure 4). Kaefer et al. (2016) also reported a reduction in the viability of maize pollen grains throughout the day. Pollen grain viability is influenced not only by intrinsic factors, such as the physiological maturation stage, origin, and genetic and nutritional traits but also by extrinsic factors, such as temperature and humidity (Stanley \& Linskens, 1974; Almeida et al., 2002). Temperature and humidity follow a normal variation throughout the day (Figure 1). It is believed that the time effect on pollen viability is directly related to the variation in temperature and humidity, such as that observed for the maize crop, in which a reduction in pollen viability was verified in the hottest hours of the day, with lower humidity, between 11:00 a.m. and 1:00 p.m. (Kaefer et al., 2016). Higher temperatures and lower humidity values were expected late in the morning and in the early afternoon (Figure 1), and the lowest viability percentages were observed at this time, corroborating the data of this experiment.

Although pollen viability was reduced at the abovementioned time, the values obtained varied from $93.46 \%$ earlier in the day (6:00 a.m.) to $86.87 \%$ at the end of the day (6:00 p.m.). Pollen viability values above $70 \%$ are considered high according to the criterion by Souza (2002). Therefore, the percentages observed in this work are satisfactory for the breeding program at any of the times.

In addition to pollen viability, flower receptivity plays a crucial role in the dynamics of pollination, reproductive success, and consequently fruit production since the stigma is the first surface of the pistil to come into contact with the pollen grain (Carpenedo et al., 2020). In this region, the formation of bubbles resulting from contact with hydrogen peroxide is observed in response to several enzymes that characterize the receptive stigma (Figure $3 \mathrm{~B}$ ), such as dehydrogenases and esterases (Shivanna \& Rangaswamy, 1992; Zulkarnain et al., 2019). A variation in bubble production was observed at the different times of the day, evidencing the time influence on the determination of stigma receptivity in Lima beans.
A quadratic behavior was also observed to explain stigma receptivity as a function of time (Figure 4). It was verified that the best receptivity occurs at 6:00 a.m., reaching approximately $88 \%$. Throughout the day, the receptivity was drastically reduced, with the minimum value observed at 12:41 p.m., corresponding to only $40.12 \%$ of receptivity, a reduction of more than $50 \%$. At the end of the day (6:00 p.m.), an increase of approximately $72 \%$ is observed in the receptivity.

It is worth noting that the high presence of bubbles at times from 10:00 a.m. to 2:00 p.m. (Figure 3C) does not occur due to the viability of the stigma but rather to some degeneration process, characterized by the presence of bubbles in the whole pistil. According to Preczehnak et al., (2011), stigma tissue begins a degeneration stage after fecundation, forming small necroses and reacting to hydrogen peroxide in its entire structure, causing the production of large amounts of bubbling. Bubble formation was also observed in the entire structure of Lima bean stigmas after pollination and fecundation (Figure $3 \mathrm{C}$ ). It is believed that high bubbling is also associated with the damage caused by the high temperatures and low humidity at these times (Figure 1); thus, bubbling was only counted on the stigmatic surface. Stigma receptivity was much more influenced by the times when compared to pollen viability. This behavior was also observed in Theobroma subincanum (Arenas de Souza, 2016). Pollen viability was greater than $95 \%$ throughout the day, although stigma receptivity was higher between 2:00 a.m. and 10:00 a.m., with a reduction from $85 \%$ to less than $69 \%$ at the end of the day (10:00 p.m.). In this manner, for the Lima beans, as well as for $T$. subincanum, stigma receptivity is the parameter that must guide the most suitable times to perform pollinations in breeding programs since this pollenstigma interaction is the initial condition to initiate the remaining processes that involve pollination and fecundation.

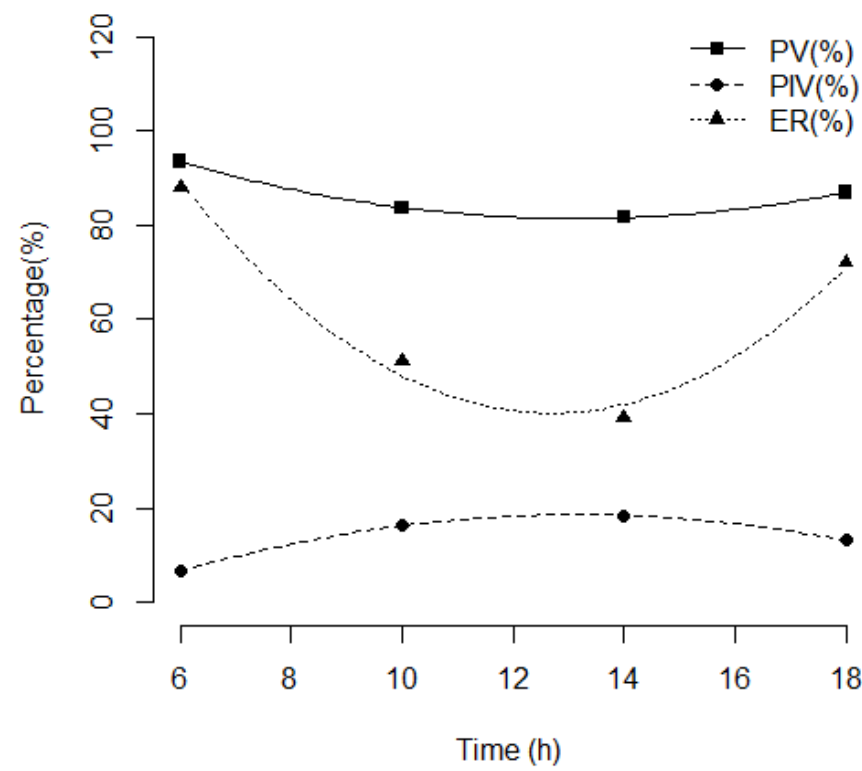

Figure 4. Percentage of viable pollen grains (PV), non-viable pollen grains (PIV), and stigma receptivity (ER) in Lima bean flowers (Phaseolus lunatus) at different times of the day. 
The early hours of the day are, therefore, the most suitable for Lima bean pollination, at 6:00 a.m. time being recommended since it provides a high percentage of viable pollen grains, and the stigma is also receptive. The positive $(0.52)$ and significant correlation $(p<0.001)$ reaffirms that the stigma is receptive at the same time that the pollen is viable. In genetic improvement, it is important to consider this effect since in addition to facilitating autogamy, the coinciding pollen maturation and receptivity of the stigma surface increased the self-pollination ability in Phaseolus lunatus L. (Bi et al., 2005), it is crucial to define hybridization strategies.

\section{Conclusion}

Pollen viability is influenced by Lima bean genotypes.

The time-of-day influences pollen viability and stigma receptivity in Lima beans.

The 6:00 a.m. time must be used to perform crosses and self-pollination in Lima beans.

\section{Acknowledgments}

To the Conselho Nacional de Desenvolvimento Científico e Tecnológico (CNPq) for the concession of the undergraduate research scholarship to the first author.

\section{Compliance with Ethical Standards}

Author contributions: Conceptualization: $\mathrm{PAB}$; Data curation: $\mathrm{PAB}, \mathrm{AMM}, \mathrm{MPLS}$; Formal analysis: $\mathrm{PAB}, \mathrm{AMM}$; Investigation: MPLB, KLSB, SCS; Methodology: PAB, SCS, $A M M$; Project administration: $P A B, S C S$; Resources: $P A B$, SCS, MPLS; Supervision: PAB, SCS; Validation: PAB, SCS; Visualization: PAB, MPLS, KLSB, AMM; Writing - original draft: PAB, MPLP; Writing - review \& editing: AMM, SCS.

Conflict of interest: The authors declare that there is no conflict of interest.

Financing source: This work has no financial funding.

\section{Literature Cited}

Almeida, C.C.S.; Amorim, E.P.; Sereno, M.J.C.M.; Barbosa Neto, J.F., Voltz, A.H. Efeito de desidratante e temperatura na estocagem de pólen de milho (Zea mays L.). In: Congresso Nacional de Milho e Sorgo, 24., 2002, Florianópolis. Anais.... Sete Lagoas: ABMS; Embrapa Milho e Sorgo; EPAGRI.

Arenas-de-Souza, M. D.; Rossi, A. A. B.; Varella, T. L.; Silveira, G. F. D.; Souza, S. A. Receptividade estigmática e viabilidade polínica em Theobroma subincanum Mart.: espécie frutífera da região amazônica. Revista Brasileira de Fruticultura. v. 38, n. 4, e-757, 2016. https://doi.org/10.1590/0100-29452016757.

Barbosa, M. V.; Sousa, E. M. L. Biologia floral, ecologia da polinização e eficiência na produção de sementes de feijão macassar (Vigna unguiculata (L.) Walp.) em sistemas agrícolas. Gaia Scientia, v.10, n.4, p.272-283, 2016. http://www.periodicos.ufpb.br/ojs/ index.php/gaia/article/view/26684/0. 04 Jun. 2019.
Bi, I. Z. A.; Maquet, A.; Baudoin, J. P. Mating system of wild Phaseolus lunatus L. and its relationship to population size. Heredity, v. 94, n. 2, p. 153-158, 2005. https://doi.org/10.1038/sj.hdy.6800527.

Brasil. Ministério da Agricultura, Pecuária e Abastecimento. CultivarWeb. Cultivares registradas.http://sistemas.agricultura. gov.br/snpc/cultivarweb/cultivares_registradas.php. 10 May. 2020.

Carpenedo, S.; Bassols, M. C.; Franzon, R. C.; Byrne, D. H.; da Silva, J. B. Stigmatic receptivity of peach flowers submitted to heat stress. Acta Scientiarum. Agronomy, v. 42, e42450-e42450, 2020. https://doi.org/10.4025/actasciagron.v42i1.42450.

Carpentieri-Pípolo, V.; Vizoni, É.; Giroto, J. C. M. Determinação do melhor período para realização de cruzamento artificial em feijão-vagem, Phaseolus vulgaris L., em Londrina, Estado do Paraná. Acta Scientiarum. Agronomy, v. 23, n.5, p. 1191-1193, 2001. https://doi.org/10.4025/actasciagron.v23i0.2573.

Dafni, A. Pollination ecology: a practical approach. Oxford: Oxford University Press, 1992. 250p.

Instituto Brasileiro de Geografia e Estatística - IBGE. Produção Agricola Municipal, 2018. https://sidra.ibge.gov.br/pesquisa/ pam/tabelas. 10 May. 2020.

Instituto Nacional de Meteorologia - INMET. Banco de Dados Meteorológicos. Disponível em: https://bdmep.inmet.gov.br/ . 30 Aug. 2021.

Jesus, L. G. A.; Tavares, L. R.; Gomes, M. F. C.; Valente, S. E. S; Gomes, R. L. F; Lopes, A. C. A.; Costa, M. F. Eficiência de testes clorimétricos para determinação da viabilidade do pólen em acessos de feijão-fava (Phaseolus lunatus L). Revista Brasileira de Agropecuária Sustentável (RBAS), v.8, n.1, p.59-64, 2018. https://periodicos.ufv.br/ojs/rbas/issue/download/122/ pdf_17. 10 May. 2020.

Kaefer, K. A. C.; Chiapetti, R.; Fogaça, L.; Muller, A. L.; Calixto, G. B.; Chaves, E. I. D. Viability of maize pollen grains in vitro collected at different times of the day. African Journal of Agricultural Research, v. 11, n.12, p. 1040-1047, 2016. https://doi. org/10.5897/AJAR2015.10181.

Munhoz, M.; Luz, C. F. P.; Filho, P. E. M.; Barth, O. M.; Reinert, F. Viabilidade polínica de Carica papaya L.: uma comparação metodológica. Revista Brasileira de Botânica, v.31, n.2, p.209-214, 2008. https://doi.org/10.1590/S0100-84042008000200003.

Ormeño-Orrillo, E.; Servín-Garcidueñas, L. E.; Rogel, M. A.; González, V.; Peralta, H.; Mora, J.; Martínez-Romero, J.; Martínez-Romero E. Taxonomy of rhizobia and agrobacteria from the Rhizobiaceae family in light of genomics. Systematic and Applied Microbiology. v. 38, n.4. p. 287-291, 2015. https://doi.org/10.1016/j. syapm.2014.12.002.

Preczehnak, A. P.; Resende, J. T. V.; Silva, P. R. Receptividade estigmática em cultivares de tomate rasteiro. Horticultura Brasileira. v.29, n.2, p.3411-3416, 2011. http://www. abhorticultura.com.br/EventosX/Trabalhos/EV_5/A4281_ T6239_Comp.pdf. 04 Jun. 2020.

R Core Team. R: A language and environment for statistical computing. Vienna: R Foundation for Statistical Computing, 2019. https://www.R-project.org/. 10 May. 2021.

Sanzol, J.; Herrero, M. Review: the effective pollination period in fruit trees. Scientia Horticulturae. v. 90, n. 1, p. 1-17. 2001. https://doi.org/10.1016/S0304-4238(00)00252-1. 
Segundo, E. S. S. Avaliação de métodos de cruzamentos artificiais em Phaseolus lunatus L. Teresina: Universidade Federal do Piauí, 2010. Trabalho Conclusão Curso.

Shivanna, K. R. Pollen biology and biotechnology. Enfield: Scienc Publishers, 2003. 301p.

Shivanna, K. R.; Rangaswamy, N. S. Pollen biology. A laborator manual. New York: Springer Verlag, 1992. 119p.

Souza, M. M.; Pereira, T. N. S.; Martins, E. R. Microsporogênese microgametogênese associadas ao tamanho do botão floral e $d$ antera eviabilidade polínica em maracujazeiro-amarelo (Passiflor edulis Sims f. flavicarpa Degener.). Ciência e Agrotecnologia, v.2€ n.6, p.1209-1217, 2002. http://www.editora.ufla.br/index.php component/phocadownload/category/50-volume-26-numero6?download=899: vol26numero6. 10 May. 2020.

Stanley, R. G.; Linskens, H. F. Pollen: biology biochemistry management. Berlin: Springer Science \& Business Media, 2012. 310p.
United States Department of Agriculture - USDA. National Agricultural Statistics Service - NASS. Census of Agriculture, 2018. https://www.nass.usda.gov/Statistics_by_Subject/index. php?sector=CROPS. 01 May. 2020.

Vaid, K. Factors in artificial crossing of dry beans (Phaseolus vulgaris L.). Legume Research, v.13, n.2, p.87-88, 1990.

Vianna, R. A. P.; Bobrowski, V. L; Silva, D. S.; Silva, D. A. Avaliação de diferentes corantes como indicadores de viabialidade do pólen de mamona. In: Congresso Brasileiro de Mamona, 2., 2006, Aracajú. Anais... Campina Grande: Embrapa Algodão, 2006.

Zulkarnain, Z.; Eliyanti, E.; Swari, E. I. Pollen viability and stigma receptivity in Swainsona formosa (G. Don) J. Thompson (Fabaceae), an ornamental legume native to Australia. Ornamental Horticulture, v.25, n.2, p.158-167, 2019. https://doi.org/10.14295/oh.v25i2.2011. 